Article

\title{
Antimicrobial and Antioxidant Activities of Essential Oils of Satureja thymbra Growing Wild in Libya
}

\author{
Abdulhmid Giweli ${ }^{1,2}$, Ana M. Džamić ${ }^{1}$, Marina Soković ${ }^{3}$, Mihailo S. Ristić ${ }^{4}$ and \\ Petar D. Marin ${ }^{1, *}$
}

1 Institute of Botany and Botanical Garden "Jevremovac", Faculty of Biology, University of Belgrade, Studentski trg 16, 11000 Belgrade, Serbia; E-Mail: simicana@bio.bg.ac.rs (A.M.D.)

2 Department of botany, Faculty of Science, University of Al-Gabel Al-Garbe, Zintan, Libya; E-Mail: zen_giweli@yahoo.com

3 Mycological Laboratory, Department of Plant Physiology, University of Belgrade-Institute for Biological Research "Siniša Stanković” Bulevar Despota Stefana 142, 11000 Belgrade, Serbia; E-Mail: mris@ibiss.bg.ac.rs

4 Institute for Medicinal Plant Research "Dr Josif Pančić”, Tadeuša Košćuška 1, 11000 Belgrade, Serbia; E-Mail: mristic@mocbilja.rs

* Author to whom correspondence should be addressed; E-Mail: pdmarin@bio.bg.ac.rs; Tel.: +38-111-324-4498; Fax: +38-111-324-3603.

Received: 24 February 2012; in revised form: 16 April 2012 / Accepted: 16 April 2012 / Published: 26 April 2012

\begin{abstract}
The composition of essential oil isolated from Satureja thymbra, growing wild in Libya, was analyzed by GC and GC-MS. The essential oil was characterized by $\gamma$-terpinene (39.23\%), thymol (25.16\%), p-cymene $(7.17 \%)$ and carvacrol $(4.18 \%)$ as the major constituents. Antioxidant activity was analyzed using the 2,2-diphenyl-1picrylhydrazyl (DPPH) free radical scavenging method. It possessed strong antioxidant activity $(\mathrm{IC} 50=0.0967 \mathrm{mg} / \mathrm{mL}$ ). The essential oil was also screened for its antimicrobial activity against eight bacterial and eight fungal species, showing excellent antimicrobial activity against the microorganisms used, in particular against the fungi. The oil of S. thymbra showed bacteriostatic activity at $0.001-0.1 \mathrm{mg} / \mathrm{mL}$ and was bactericidal at $0.002-0.2 \mathrm{mg} / \mathrm{mL}$; fungistatic effects at $0.001-0.025 \mathrm{mg} / \mathrm{mL}$ and fungicidal effects at $0.001-0.1 \mathrm{mg} / \mathrm{mL}$. The main constituents thymol, carvacrol and $\gamma$-terpinene also showed strong antimicrobial activity. The commercial fungicide bifonazole showed much lower antifungal activity than the tested oil.
\end{abstract}


Keywords: Satureja thymbra; essential oil; antimicrobial; antioxidant activity; $\gamma$-terpinene; thymol; carvacrol

\section{Introduction}

Species of the genus Satureja (family Lamiaceae) are widely distributed in the Mediterranean area, Asia and boreal America, regularly found in sunny, dry, rocky habitats. Satureja consists of about 200 species, usually aromatic herbs and shrubs. In Libya, this genus is represented by only two species - S. thymbra and S. fortii the second being endemic to Libya. The two species could be found only in the Green Mountains (Eastern Libya) [1]. S. thymbra L. is a very branched, usually grey-puberulent dwarf shrub, 20-35 cm [2]. In Europe, this species is distributed in the South Aegean region and the south coast of Sardinia.

A number of studies have focused on the chemical characteristics of natural flora of a specific region or country. This criterion may be useful for understanding the activity of plants used in folk medicine in different parts of the World, and it is a valuable as an ethnopharmacological criterion, which is important in characterization of some oil chemotypes [3]. The essential oil of this species is used in folk medicine as an antiseptic, tonic, gastric sedative and diuretic [4]. Also, the aerial parts of some Satureja plants have been widely used in folk and traditional medicine, to treat many ailments, for instance muscle pains, indigestion, cramps, nausea, diarrhea and infectious diseases $[5,6]$. In addition, they are used traditionally as an antibacterial for the treatment of cold and bronchitis [7].

$S$. thymbra oil has been found to have a good antimicrobial activity against various bacteria and fungi [7-9]. It has also been evaluated for inhibitory activity against SARS-CoV and HSV-1 replication in vitro by visually scoring of the virus-induced cytopathogenic effects post-infection [10]. The essential oil of $S$. thymbra (1\%), as well as its hydrosol fraction (100\%). have also been reported to present strong bactericidal effects against bacterial biofilms formed on stainless steel by some useful, technological and pathogenic bacteria [11].

Recently, the acaricidal activity of $S$. thymbra essential oil and its major components carvacrol and $\gamma$-terpinene were tested against adult Hyalomma marginatum (Acari: Ixodidae) [12]. In addition, insecticidal activity of the essential oils from this and related plant species was evaluated against three stored-product insects [13].

It has been shown that essential oil content and composition is related to genetic [14], edaphic, climate, topography, altitude [15,16], genotype and growing conditions [17]). Different chemotypes have been described for a number of medicinal plants [14,18-20]. Also, several recent results have shown that some medicinal plant characteristics can be affected by ecological factors such as temperature, plant competition, nitrogen content in the soil and precipitation [21].

So far, several articles were published dealing with the essential oil of $S$. thymbra $[8,10,22-29]$. Its constituents were determined to be mainly carvacrol, thymol, $p$-cymene, and $\gamma$-terpinene. However, significant differences were reported in essential oil composition in samples from different regions. In addition, according to recent results of essential oil composition of this species collected from two locations in Greece, the authors found different chemotypes [24]. 
These aspects of many medicinal plants from Libyan flora are still insufficiently investigated. To the best of our knowledge, there are no previous reports on chemical composition and biological activity of essential oil of $S$. thymbra originating from this area. The aims of this study were to characterize the composition of the essential oil of wild-growing S. thymbra from Libya and compare it with other reported results of samples of this species collected from various areas of its natural distribution, since different oil compositions were published so far. The goal was also to test the antioxidant, antifungal and antibacterial activities of the analyzed essential oil as a potentially new source of biologically active natural products.

\section{Results and Discussion}

The composition of the essential oil isolated from $S$. thymbra is given in Table 1 . The essential oil was characterized by $\gamma$-terpinene $(39.26 \%)$, thymol $(25.16 \%), p$-cymene $(7.17 \%)$ and carvacrol $(4.18 \%)$ as the major constituents. Our findings are in contrast with some previous observations of S. thymbra essential oil [10,13,22-28,30,31]. In most references mentioned, carvacrol and/or thymol were the major compounds. Thus, the essential oil composition of $S$. thymbra from Turkey contained mainly carvacrol and $\gamma$-terpinene [25]. S. thymbra essential oil from Lebanon was characterized by similar amounts of $p$-cymene (10.76\%), $\alpha$-pinene (10.15\%), thymol (9.92\%) and sabinene (8.64\%) [10]. According to the essential oil composition of this species collected from Crete (Greece) from two locations, it presented different chemotypes. In the sample from Aktotiri the major compounds were carvacrol, thymol, $p$-cymene and $\gamma$-terpinene $(44.6 \%, 0.3 \%, 11.9 \%$ and $25.5 \%$ respectively), while in the other sample the main compounds were thymol (35.5\%), $\gamma$-terpinene $(27.6 \%), p$-cymene $(10.4 \%)$ and carvacrol (3.2\%) [24]. The essential oil of the same species growing wild in Turkey was also dominated by carvacrol (53.7\%), followed by $\gamma$-terpinene $(17.6 \%)$, thymol $(13 \%)$ and $p$-cymene $(10.1 \%)$ [13]. Furthermore, in a study of the essential oil composition of samples from 13 essential oils of $S$. thymbra from different locations in Crete, the findings showed a high compositional variation in which carvacrol varied significantly (5.2-65\%), thymol $(0.1-65.6 \%), \gamma$-terpinene $(20-4.4 \%)$ and cymene (5.5-15\%) [22]. Moreover, a study was carried out to evaluate the effect of harvesting time on essential oil composition of $S$. thymbra collected from the same location at different vegetation stages. The findings showed that the major compounds in the vegetation phase were thymol $(27.88 \%)$, followed by $\gamma$-terpinene $(17.02 \%)$ and carvacrol $(11.88 \%)$, while in full flowering phase carvacrol (29.18\%), thymol (17.22\%) and $\gamma$-terpinene (12.45\%) were the main compounds, and in the fruiting phase thymol $(20.73 \%)$ was again the main compound, followed by $\gamma$-terpinene $14.91 \%$ and carvacrol $12.8 \%$ [26].

The differences in essential oil composition found by various authors may be explained, at least partially, by different ecological conditions and/or harvesting time of the investigated plant materials. According to literature data and our results, it is obvious that there are some differences in the essential oil composition of $S$. thymbra. However, its principal constituents were determined to be mainly carvacrol, thymol, $p$-cymene, and $\gamma$-terpinene, and very rarely $\alpha$-pinene and sabinene. It has also been reported that the quantitative composition of the oil is related to the plant habitat [22]. 
Table 1. Chemical composition of essential oil of S. thymbra.

\begin{tabular}{|c|c|c|c|}
\hline Constituents & ${ }^{\mathrm{a}} \mathbf{K I E}$ & ${ }^{\mathrm{b}} \mathbf{K I L}$ & $\%$ \\
\hline$\alpha$-thujene & 917.7 & 924 & $1.55 \pm 0.02$ \\
\hline$\alpha$-pinene & 923.4 & 932 & $1.48 \pm 0.03$ \\
\hline camphene & 937.4 & 946 & $0.69 \pm 0.01$ \\
\hline sabinene & 963.6 & 969 & $0.14 \pm 0.00$ \\
\hline$\beta$-pinene & 965.7 & 974 & $0.70 \pm 0.01$ \\
\hline myrcene & 983.2 & 988 & $1.76 \pm 0.01$ \\
\hline$\alpha$-phellandrene & 995.4 & 1002 & $0.28 \pm 0.00$ \\
\hline$\delta^{3}$-carene & 1001.2 & 1008 & $0.10 \pm 0.01$ \\
\hline$\alpha$-terpinene & 1007.8 & 1014 & $3.26 \pm 0.02$ \\
\hline$p$-cymene & 1016.1 & 1020 & $7.17 \pm 0.05$ \\
\hline sylvestrene & 1019.5 & 1025 & $0.78 \pm 0.01$ \\
\hline cis- $\beta$-ocimene & 1030.6 & 1032 & $0.52 \pm 0.00$ \\
\hline trans- $\beta$-ocimene & 1040.6 & 1044 & $0.81 \pm 0.01$ \\
\hline$\gamma$-terpinene & 1051.5 & 1054 & $39.23 \pm 0.27$ \\
\hline cis-sabinene hydrate & 1060.6 & 1065 & $0.23 \pm 0.01$ \\
\hline terpinolene & 1079.1 & 1086 & $0.11 \pm 0.00$ \\
\hline linalool & 1051.5 & 1095.6 & $0.34 \pm 0.00$ \\
\hline borneol & 1157.2 & 1165 & $0.82 \pm 0.00$ \\
\hline terpinen-4-ol & 1169.4 & 1174 & $0.36 \pm 0.01$ \\
\hline$\alpha$-terpineol & 1185.3 & 1186 & $0.05 \pm 0.01$ \\
\hline neo-dihydro carveol & $\mathrm{n} / \mathrm{a}$ & 1193 & $0.06 \pm 0.04$ \\
\hline carvacrol methyl ether & 1235.6 & 1241 & $3.33 \pm 1.88$ \\
\hline thymol & 1291.0 & 1289 & $25.16 \pm 1.95$ \\
\hline carvacrol & 1297.9 & 1298 & $4.18 \pm 0.23$ \\
\hline thymyl acetate & 1346.9 & 1349 & $0.21 \pm 0.21$ \\
\hline$\beta$-caryophyllene & 1407.1 & 1417 & $2.76 \pm 0.03$ \\
\hline aromadendrene & 1426.5 & 1439 & $0.36 \pm 0.01$ \\
\hline$\alpha$-humulene & 1441.3 & 1452 & $0.15 \pm 0.00$ \\
\hline alloaromadendrene & 1448.4 & 1458 & $0.22 \pm 0.22$ \\
\hline cis- $\beta$-guaiene & 1484.6 & 1492 & $1.56 \pm 0.02$ \\
\hline spathulenol & 1565.9 & 1577 & $0.95 \pm 0.03$ \\
\hline caryophyllene oxide & 1570.0 & 1582 & $0.32 \pm 0.01$ \\
\hline cis- $\alpha$-bergamotene & ${ }^{\mathrm{c}} \mathrm{n} / \mathrm{a}$ & & $0.17 \pm 0.16$ \\
\hline Total & & & $99.81 \%$ \\
\hline Yield (v/w) \% & & & 4.9 \\
\hline Number of constituents & & & 33 \\
\hline Monoterpene hydrocarbons & & & $58.57 \%$ \\
\hline Oxygenated monoterpenes & & & $31.21 \%$ \\
\hline Sesquiterpene hydrocarbons & & & $5.23 \%$ \\
\hline Oxygenated hydrocarbons & & & $1.27 \%$ \\
\hline Other & & & $3.53 \%$ \\
\hline
\end{tabular}


Antioxidant activity was analyzed using the DPPH free radical scavenging method. The results of the DPPH scavenging assay of $S$. thymbra essential oil and its principal components and the synthetic antioxidant butylated hydroxyanisole (BHA) are shown in Figure 1. The results showed that S. thymbra essential oil possessed strong antioxidant activity, as seen from the concentrations at which $50 \%$ radical scavenging occurred $\left(\mathrm{IC}_{50}=0.0967 \mathrm{mg} / \mathrm{mL}\right.$ ), being better than $\gamma$-terpinene and thymol and quite similar to BHA. It has been shown that the $\mathrm{IC}_{50}$ of Origanum vulgare essential oil, which was dominated by $\gamma$-terpinene and thymol (34.4\% and 31.8\%, respectively) was better than BHA [32]. Moreover, $O$. vulgare essential oil, containing $49 \%$ of $\gamma$-terpinene and $15 \%$ of thymol, showed an $\mathrm{IC}_{50}$ value quite similar to our results. Also, carvacrol, present in relative high amounts in Thymbra capitata oil can be partly responsible for high antioxidant activity, whereas in $O$. vulgare oil the activity may be attributed to two components, $\gamma$-terpinene and thymol [33]. According to earlier reports, some structural features, such as the presence of strongly activated methylene groups in the molecule, are probably the reason for antioxidant activity of monoterpene hydrocarbons [34].

Figure 1. Comparison between the $\mathrm{IC}_{50}$ values $(\mathrm{mg} / \mathrm{mL})$ of $S$. thymbra essential oil, thymol, carvacrol, $\gamma$-terpinene and BHA on DPPH assay.

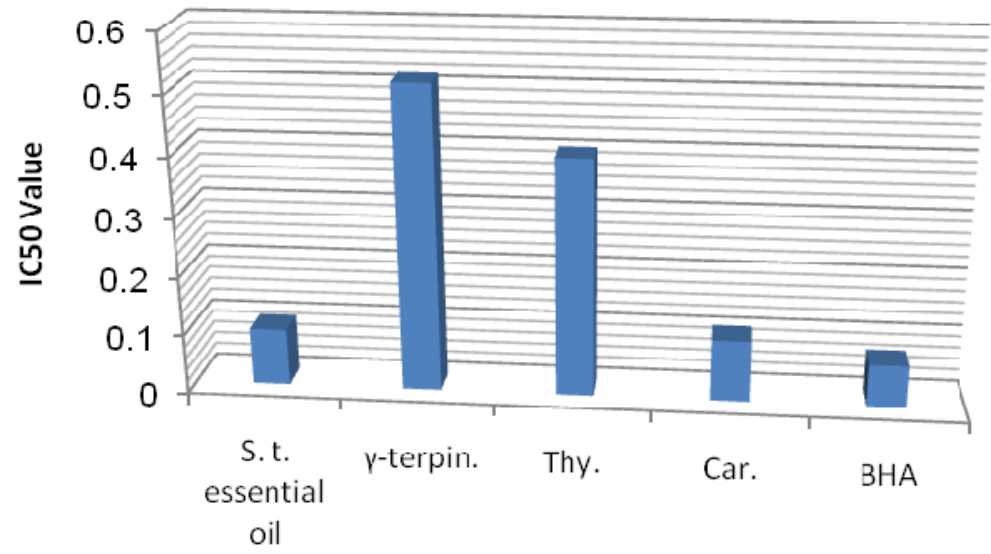

S. thymbra essential oil (S.t.essential oil), $\gamma$-terpinene ( $\gamma$-terpin), Thymol (Thy.), Carvacrol (Car.) and BHA

Antibacterial activity results of the tested essential oil are presented in Table 2 . The oil was active against all the bacteria tested. $S$. thymbra essential oil showed bacteriostatic effects at $0.001-0.1 \mathrm{mg} / \mathrm{mL}$ and bactericidal ones at $0.002-0.2 \mathrm{mg} / \mathrm{mL}$. Thymol exhibited high antibacterial activity with a minimum inhibitory concentration (MIC) at $0.01-0.1 \mathrm{mg} / \mathrm{mL}$ and minimum bactericidal concentration (MBC) at $0.05-0.15 \mathrm{mg} / \mathrm{mL}$, while carvacrol showed stronger bacteriostatic activity at $0.0025-0.05 \mathrm{mg} / \mathrm{mL}$ and bactericidal activity at $0.005-0.1 \mathrm{mg} / \mathrm{mL}$. Inhibitory and bactericidal concentrations for $\gamma$-terpinene were slightly higher than for previous compounds (MIC at $0.05-0.2 \mathrm{mg} / \mathrm{mL}$, and $\mathrm{MBC}$ at $0.07-0.3 \mathrm{mg} / \mathrm{mL}$ ). Streptomycin expressed inhibitory effects at $0.0005-0.001 \mathrm{mg} / \mathrm{mL}$ and bactericidal activity at $0.0005-0.002 \mathrm{mg} / \mathrm{mL}$. It can be seen that the essential oil showed the highest bactericidal activity $(\mathrm{MBC}=0.002 \mathrm{mg} / \mathrm{mL})$ against Micrococcus flavus and the lowest $(\mathrm{MBC}=0.2 \mathrm{mg} / \mathrm{mL})$ against Listeria monocytogenes. However, S. thymbra essential oil showed lower antibacterial activity than streptomycin, and was quite similar to thymol $(\mathrm{MIC}=0.01-0.1 \mathrm{mg} / \mathrm{mL}$ and $\mathrm{MBC}=0.05-0.15 \mathrm{mg} / \mathrm{mL})$ and slightly lower or similar to carvacrol 
$(\mathrm{MIC}=0.0025-0.025 \mathrm{mg} / \mathrm{mL}$ and $\mathrm{MBC}=0.005-0.1 \mathrm{mg} / \mathrm{mL})$, and it was stronger or similar to $\gamma$-terpinene (MIC at $0.05-0.2 \mathrm{mg} / \mathrm{mL}$, and $\mathrm{MBC}$ at $0.07-0.3 \mathrm{mg} / \mathrm{mL}$ ).

Table 2. Antibacterial activity of $S$. thymbra essential oil and their main compounds tested by microdilution method (MIC and $\mathrm{MBC}$ in $\mathrm{mg} / \mathrm{mL}$ ).

\begin{tabular}{llllllllllll}
\hline \multirow{2}{*}{ Bacteria } & \multicolumn{3}{l}{ S. thymbra } & \multicolumn{3}{c}{$\boldsymbol{\gamma}$-terpenene } & \multicolumn{2}{c}{ thymol } & \multicolumn{2}{c}{ carvacrol } & \multicolumn{2}{c}{ streptomycin } \\
\cline { 2 - 11 } & MIC & MBC & MIC & MBC & MIC & MBC & MIC & MBC & MIC & MBC \\
\hline Gram (+) bacteria & & & & & & & & & & \\
Bacillus cereus & 0.05 & 0.1 & 0.05 & 0.07 & 0.025 & 0.05 & 0.0125 & 0.025 & 0.0005 & 0.0005 \\
Micrococcus flavus & 0.001 & 0.002 & 0.05 & 0.07 & 0.025 & 0.05 & 0.0025 & 0.005 & 0.0005 & 0.001 \\
Staphylococcus aureus & 0.05 & 0.1 & 0.05 & 0.1 & 0.025 & 0.05 & 0.025 & 0.05 & 0.001 & 0.001 \\
Listeria monocytogenes & 0.1 & 0.2 & 0.1 & 0.2 & 0.1 & 0.1 & 0.05 & 0.05 & 0.001 & 0.002 \\
Gram (-) bacteria & & & & & & & & & & \\
Escherichia coli & 0.05 & 0.1 & 0.15 & 0.2 & 0.1 & 0.15 & 0.05 & 0.05 & 0.0005 & 0.001 \\
Pseudomonas aeruginosa & 0.05 & 0.1 & 0.15 & 0.3 & 0.1 & 0.15 & 0.05 & 0.1 & 0.001 & 0.002 \\
Proteus mirabilis & 0.05 & 0.1 & 0.2 & 0.3 & 0.01 & 0.15 & 0.05 & 0.1 & 0.001 & 0.002 \\
Salmonella typhimurium & 0.05 & 0.1 & 0.1 & 0.2 & 0.05 & 0.1 & 0.05 & 0.05 & 0.001 & 0.001 \\
\hline
\end{tabular}

Results of antifungal activity of compounds tested are presented in Table 3. As in the case of the antibacterial activity, the oils showed strong antifungal potential. $S$. thymbra oil possessed strong activity with (MIC) $0.001-0.025 \mathrm{mg} / \mathrm{mL}$ and showed fungicidal effects at $0.001-0.1 \mathrm{mg} / \mathrm{mL}$. MIC and the MFC for thymol are $0.01-0.05 \mathrm{mg} / \mathrm{mL}$, while carvacrol showed MIC at $0.0025-0.025 \mathrm{mg} / \mathrm{mL}$ and MFC at $0.005-0.05 \mathrm{mg} / \mathrm{mL}$. MIC and (MFC) for $\gamma$-terpinene were at $0.015-0.05 \mathrm{mg} / \mathrm{mL}$ and $0.02-0.1 \mathrm{mg} / \mathrm{mL}$. Bifonazole showed lower antifungal activity than the tested oils. MIC was at $1.5-2 \mathrm{mg} / \mathrm{mL}$ and MFC $2-2.5 \mathrm{mg} / \mathrm{mL}$. Penicillium ochrochloron was the most sensitive fungus, with MBC at $0.001 \mathrm{mg} / \mathrm{mL}$, while Candida albicans was the most resistant species when treated with this oil. Fungi were in general more sensitive than bacterial species (Tables 2 and 3). In general, S. thymbra essential oil showed antifungal activity similar or lower than thymol (MIC and MFC $0.01-0.05 \mathrm{mg} / \mathrm{mL}$ ) and lower than carvacrol (MIC at $0.0025-0.025$ and MFC at $0.005-0.05 \mathrm{mg} / \mathrm{mL}$ ), and it was slightly better or similar to $\gamma$-terpinene $(0.015-0.05 \mathrm{mg} / \mathrm{mL}$ and $0.02-0.1 \mathrm{mg} / \mathrm{mL})$.

Table 3. Antifungal activity of $S$. thymbra essential oil and their main compounds tested by microdilution method (MIC and MFC in $\mathrm{mg} / \mathrm{mL}$ ).

\begin{tabular}{|c|c|c|c|c|c|c|c|c|c|c|}
\hline \multirow{2}{*}{ Fungi } & \multicolumn{2}{|c|}{ S. thymbra } & \multicolumn{2}{|c|}{$\gamma$-terpenene } & \multicolumn{2}{|l|}{ thymol } & \multicolumn{2}{|c|}{ carvacrol } & \multicolumn{2}{|c|}{ Bifonazole } \\
\hline & MIC & MFC & MIC & MFC & MIC & MFC & MIC & MFC & MIC & MFC \\
\hline Penicillium funiculosum & 0.025 & 0.05 & 0.025 & 0.07 & 0.0125 & 0.025 & 0.0125 & 0.0125 & 2.0 & 2.5 \\
\hline Penicillium ochrochloron & 0.001 & 0.001 & 0.025 & 0.07 & 0.025 & 0.025 & 0.0025 & 0.005 & 1.5 & 2.0 \\
\hline Aspergillus fumigatus & 0.025 & 0.05 & 0.05 & 0.07 & 0.025 & 0.05 & 0.025 & 0.025 & 1.5 & 2.0 \\
\hline Aspergillus niger & 0.025 & 0.05 & 0.02 & 0.03 & 0.01 & 0.02 & 0.025 & 0.025 & 1.5 & 2.0 \\
\hline Aspergillus flavus & 0.025 & 0.05 & 0.02 & 0.03 & 0.01 & 0.01 & 0.005 & 0.01 & 1.5 & 2.0 \\
\hline Aspergillus ochraceus & 0.025 & 0.05 & 0.015 & 0.02 & 0.01 & 0.015 & 0.005 & 0.01 & 1.5 & 2.0 \\
\hline Candida albicans & 0.025 & 0.1 & 0.05 & 0.1 & 0.05 & 0.05 & 0.025 & 0.05 & 1.5 & 2.0 \\
\hline Trichoderma viride & 0.025 & 0.05 & 0.05 & 0.07 & 0.01 & 0.01 & 0.005 & 0.01 & 2.0 & 2.5 \\
\hline
\end{tabular}


Satureja oils represent an inexpensive source of natural antibacterial substances that exhibit potential for use in food systems to prevent the growth of foodborne bacteria and to extend the shelf life of processed foods [26]. More recently, [11] concluded that the essential oil of S. thymbra (1\%), as well as its hydrosol fraction (100\%), present sufficient bactericidal effect on bacterial biofilms formed on stainless steel suggesting that the use of natural antimicrobial agents could provide alternative or supplementary ways for the disinfection of microbial-contaminated industrial surfaces.

Previous investigations showed that the essential oil of $S$. thymbra was found to be active against the bacteria E. coli, P. aeruginosa, S. typhimurium, S. sonnei and S. aureus and the yeast C. albicans [7]. $S$. thymbra essential oil from Greece possessed very good antifungal properties with low MIC $(0.1-1.0 \mu \mathrm{L} / \mathrm{mL})$ and MFC $(0.2-2.0 \mu \mathrm{L} / \mathrm{mL})$ values [23]. The antifungal activity results of $S$. thymbra oil against $M$. perniciosa, a contaminator of Agaricus bisporus, obtained by the micro atmosphere method, showed MIC of $0.001-0.05 \mu \mathrm{L} / \mathrm{mL}$ and MFC of $0.1-0.25 \mu \mathrm{L} / \mathrm{mL}$ [35]. More recently, it has been shown that the oil of $S$. thymbra exhibited minimum inhibitory concentration (MIC) in the range of $0.6-5.0 \mu \mathrm{g} / \mathrm{mL}$, and minimum bactericidal concentration (MBC) in the range of $2.5-10.0 \mu \mathrm{g} / \mathrm{mL}$, while fungi were more sensitive with MIC and MFC at $1.25-2.5 \mu \mathrm{g} / \mathrm{mL}$, and fungicidal activity in range of $2.5-5.0 \mu \mathrm{g} / \mathrm{mL}[36]$.

It is evident that there is a relationship between the high activity of tested oil and the presence of phenol components such as thymol and carvacrol. It seems likely that thymol and carvacrol interfere with the activity of cell wall enzymes like chitin synthase/chitinase as well as $\alpha$ - and $\beta$-glucanases of fungi [37,38]. According to literature data, the mode of action of essential oils against bacteria cannot be attributed to one specific mechanism, and not all of these mechanisms are separate targets, some are affected as a result of another mechanism being targeted $[39,40]$. One of important action of essential oils against bacteria is their hydrophobicity, which enables them to partition in the lipids of the bacterial cell membrane and mitochondria, disturbing the structures and rendering them more permeable and leading to leakage of cell content [41-43]. Although a certain amount of leakage from bacterial cells may be tolerated without loss of viability, extensive loss of cell contents or the exit of critical molecules and ions will lead to death [44]. Consequently, the high content of phenolic components may account for the high antimicrobial activity of carvacrol-type oils [45]. It should be noted that the antimicrobial activity of $S$. thymbra against the pathogenic bacteria and fungi was lower (or equal) as compared to the essential oils compounds tested here-thymol and carvacrol. Presumably, this activity is not derived only from the presence of these phenols, but part of the activity resulted from the effect of minor active constituents. Thus, synergistic or antagonistic activity between some components may affect the observed antimicrobial activity of the oils. In the study of Cosentino et al. [46], the high p-cymene content observed in Sardinian T. capitatus and T. herba-barona 'sample a' may have antagonized the antimicrobial action of phenols, resulting in a weaker activity of these oils, in comparation to thymol and carvacrol. This may explain in part the higher activity of thymol and carvacrol when evaluated separately. Also, some authors discussed synergistic and antagonistic effect of components and essential oils [47]. They concluded that the effects of thymol and carvacrol are responsible for the different antibacterial activities of the essential oil of various oil chemotypes. On the other hand, there are also some reports concerning a disadvantageous antagonistic effect, weakening the essential oil action as compared with its constituents. 
The oil and components tested in here showed higher antibacterial activity against Gram (+) than Gram (-) bacteria. Gram negative bacteria are, in general, more resistant than Gram positive ones [48-55]. Overall, the oils and single compounds were more active $v s$. yeasts and Gram positive bacteria than Gram negatives, has reported in similar studies [43,46,56-58].

\section{Experimental}

\subsection{Plant Material}

The samples from wild growing samples of the investigated plants were collected during the flowering stage from Bayda town in the Green Mountain region of Eastern Libya in March 2010. The plants were identified by Dr. A. Felaly, Faculty of Science, Al-Gabel Al-Garbi University Libya, and later confirmed by one of the authors (P.D.M.). The samples were dried in shadow at room temperature for 10 days. Voucher specimens where deposited in Herbarium of Institute of Botany and Botanical Garden “Jevremovac” (BEOU; voucher No. 16618).

\subsection{Isolation of the Essential Oil}

Air-dried aerial parts of Satureja thymbra with the wooden parts removed (100 g) were submitted to hydrodistillation, using a Clevenger-type apparatus for $3 \mathrm{~h}$, according to the British Pharmacopoeia specifications [59]. The obtained essential oil was dried over anhydrous sodium sulphate, and stored in sealed dark vials kept at $4{ }^{\circ} \mathrm{C}$. The oil yields $(\mathrm{v} / \mathrm{w})$ on a dry weight basis are reported in Table 1 .

\subsection{Gas Chromatography and Gas Chromatography-Mass Spectrometry Analysis}

Qualitative and quantitative analyses of the oils were performed using GC and GC-MS. The GC analysis of the oil was carried out on a GC HP-5890 II apparatus, equipped with a split-splitless injector, attached to a HP-5 column $(25 \mathrm{~m} \times 0.32 \mathrm{~mm}, 0.52 \mu \mathrm{m}$ film thickness $)$ and equipped with a FID detector. Carrier gas flow rate $\left(\mathrm{H}_{2}\right)$ was $1 \mathrm{~mL} / \mathrm{min}$, split ratio 1:30, injector temperature was $250{ }^{\circ} \mathrm{C}$, detector temperature $300{ }^{\circ} \mathrm{C}$, while column temperature was linearly programmed from $40-240{ }^{\circ} \mathrm{C}$ (at rate of $4 \% \mathrm{~min}$ ). The same analytical conditions were employed for GC-MS analysis, where a HP G 1800C Series II GCD system equipped with a HP-5MS column $(30 \mathrm{~m} \times 0.25 \mathrm{~mm}$, $0.25 \mu \mathrm{m}$ film thickness) was used. Transfer line was heated at $260{ }^{\circ} \mathrm{C}$. Mass spectra were acquired in EI mode $(70 \mathrm{eV})$, in the $40-400 \mathrm{~m} / \mathrm{z}$ range. Identification of the individual oil components was accomplished by comparison of retention times with standard substances and by matching mass spectral data with those held in the Wiley 275 Library of Mass Spectra. Confirmation was performed using the AMDIS software and literature data [60]. For the purposes of quantitative analysis area percent obtained from the FID were used as a base.

\subsection{Antioxidant Activity (DPPH Assay)}

Radical scavenging of the DPPH radical is considered to be one of the main mechanisms by which antioxidant acts in food systems. The DPPH method we used in this study was as described earlier [61]. The stable 2,2-diphenyl-1-picrylhydrazyl radical (DPPH) was used for determination of free 
radical-scavenging activity of the oils and their main compounds (thymol, carvacrol and $\gamma$-terpinene). A solution $(0.04 \mathrm{mg} / \mathrm{mL})$ was prepared, and then $1,800 \mu \mathrm{L}$ of this solution was added to $200 \mu \mathrm{L}$ of essential oils in methanol at different concentrations. The absorbance of the remaining DPPH radical was measured spectrophotometrically at $517 \mathrm{~nm}$ using a Jenway $6305 \mathrm{UV} / \mathrm{V}$ is spectrophotometer (Keison Products, Chelmsford, Essex, England) after $30 \mathrm{~min}$ at room temperature for all samples. Methanol was used as a blank, while methanol with DPPH solution was used as a control. All determinations were taken in triplicate and special care was taken to minimize the loss of free radical activity of the DPPH. Butylated hydroxyanisole (BHA) was used as a positive control. DPPH scavenging capacity expressed in percentage (\%) was calculated using the following equation:

$$
\% \text { inhibition }=\left[\left(A_{0}-A_{1}\right) / A_{0}\right] \times 100
$$

where $A_{0}$ is the absorbance of control sample (without essential oils), and $A_{1}$ is the absorbance of the samples with essential oils at different concentrations. Oil concentrations $(\mathrm{mg} / \mathrm{mL})$ providing $50 \%$ inhibition $\left(\mathrm{IC}_{50}\right)$ was calculated from a graph plotting scavenging activity against oil concentration.

\subsection{Antifungal Activity}

For the antifungal bioassay eight fungi were used: Aspergillus flavus (ATCC 9643), Aspergillus fumigatus (human isolate), Aspergillus niger (ATCC 6275), Aspergillus ochraceus (ATCC 12066), Penicillium funiculosum (ATCC 36839), Penicillium ochrochloron (ATCC 9112), Trichoderma viride (IAM 5061) and Candida albicans (human isolate). The organisms were obtained from the Mycological Laboratory, Department of Plant Physiology, Institute for Biological Research "Siniša Stanković", Belgrade, Serbia. The micromycetes were maintained on malt agar and the cultures stored at $4{ }^{\circ} \mathrm{C}$ and sub-cultured once a month [62]. In order to investigate the antifungal activity of the extracts, a modified microdilution technique was used [63-65]. The fungal spores were washed from the surface of agar plates with sterile $0.85 \%$ saline containing $0.1 \%$ Tween $80(\mathrm{v} / \mathrm{v})$. The spore suspension was adjusted with sterile saline to a concentration of approximately $1.0 \times 10^{5}$ in a final volume of $100 \mu \mathrm{L}$ per well. The inocula were stored at $4{ }^{\circ} \mathrm{C}$ for further use. Dilutions of the inocula were cultured on solid malt agar to verify the absence of contamination and to check the validity of the inoculum. Minimum inhibitory concentration (MIC) determinations were performed by a serial dilution technique using 96-well microtiter plates. The compounds investigated were added in broth Malt medium with inoculum. The microplates were incubated for $72 \mathrm{~h}$ at $28{ }^{\circ} \mathrm{C}$. The lowest concentrations without visible growth (at the binocular microscope) were defined as MICs. The fungicidal concentrations (MFCs) were determined by serial subcultivation of a $2 \mu \mathrm{L}$ aliquot into microtiter plates containing $100 \mu \mathrm{L}$ of broth per well and further incubation for $72 \mathrm{~h}$ at $28{ }^{\circ} \mathrm{C}$. The lowest concentration with no visible growth was defined as MFC indicating $99.5 \%$ killing of the original inoculum. DMSO was used as a negative control, and the commercial fungicide bifonazole was used as positive control $(1-3,000 \mu \mathrm{g} / \mathrm{mL})$.

\subsection{Antibacterial Activity}

The following Gram-negative bacteria were used: Escherichia coli (ATCC 35210), Pseudomonas aeruginosa (ATCC 27853), Salmonella typhimurium (ATCC 13311), Proteus mirabilis 
(human isolate) and the following Gram-positive bacteria: Listeria monocytogenes (NCTC 7973), Bacillus cereus (clinical isolate), Micrococcus flavus (ATCC 10240), and Staphylococcus aureus (ATCC 6538). The organisms were obtained from the Mycological Laboratory, Department of Plant Physiology, Institute for Biological Research "Siniša Stanković”, Belgrade, Serbia. The antibacterial assay was carried out by microdilution method [63-65] in order to determine the antibacterial activity of compounds tested against the human pathogenic bacteria. The bacterial suspensions were adjusted with sterile saline to a concentration of $1.0 \times 10^{5} \mathrm{CFU} / \mathrm{mL}$. The inocula were prepared daily and stored at $+4{ }^{\circ} \mathrm{C}$ until use. Dilutions of the inocula were cultured on solid medium to verify the absence of contamination and to check the validity of the inoculum.

The minimum inhibitory and bactericidal concentrations (MICs and MBCs) were determined using 96-well microtitre plates. The bacterial suspension was adjusted with sterile saline to a concentration of $1.0 \times 10^{5} \mathrm{cfu} / \mathrm{mL}$. Compounds to be investigated were dissolved in broth LB broth $(100 \mu \mathrm{L})$ with bacterial inoculum $\left(1.0 \times 10^{4} \mathrm{cfu}\right.$ per well) to achieve the wanted concentrations $(1 \mathrm{mg} / \mathrm{mL})$. The microplates were incubated for $24 \mathrm{~h}$ at $37{ }^{\circ} \mathrm{C}$. The lowest concentrations without visible growth (at the binocular microscope) were defined as concentrations that completely inhibited bacterial growth (MICs). The MBCs were determined by serial sub-cultivation of $2 \mu \mathrm{L}$ into microtitre plates containing $100 \mu \mathrm{L}$ of broth per well and further incubation for $72 \mathrm{~h}$. The lowest concentration with no visible growth was defined as the $\mathrm{MBC}$, indicating $99.5 \%$ killing of the original inoculum. The optical density of each well was measured at a wavelength of $655 \mathrm{~nm}$ by Microplate Manager 4.0 (Bio-Rad Laboratories) and compared with a blank and a positive control. Streptomycin was used as a positive control (1 $\mathrm{mg} / \mathrm{mL}$ DMSO). Two replicates were done for each compound and experiments were repeated three times.

\section{Conclusions}

Our results showed that $S$. thymbra essential oil exhibited strong antioxidant activity, even higher than $\gamma$-terpinene and thymol, compounds which are well known as potent antioxidants, and quite similar to commercial BHA. It can also be concluded that the essential oils of all Satureja species possess strong antimicrobial activities to different extents against organisms of importance to food spoilage and/or poisoning (Salmonella, Listeria, Penicillium and Aspergillus), as well as to those of interest to the medical field such as Staphyloccocus, Apergillus fumigatus and Candida. The majority of the essential oils are classified as Generally Recognized As Safe (GRAS) [66], Their use in foods as preservatives could be limited due to flavor considerations, since effective antimicrobial doses may exceed organoleptically acceptable levels. Still, there are strong consumer trends towards natural alternatives to chemical antimicrobial agents and this is supported by changes in legislation. Therefore, there is an increasing demand for accurate knowledge of the minimum inhibitory (effective) concentrations (MIC) of essential oils to enable a balance between the sensory acceptability and antimicrobial efficacy in the food matrix, preparation and possible toxicology. Addition of oils is therefore not problematic especially not when used in such a small amount as we define according to the MIC's and MBC/MFC's obtained in this study. In view of broad activity, this essential oil may find industrial applications as natural preservatives and conservation agent in the cosmetic and/or food industries and as active ingredient in medical preparations. 


\section{Acknowledgments}

This study was supported by the Ministry of Education and Science of Serbia (Projects No. 173029 and 173032).

\section{References and Notes}

1. Jafri, S.M.H.; El-Gadi, A. Flora of Libya; Al Faateh University, Faculty of Science, Department of Botany: Tripoli, Libya, 1985, Volume 118, pp. 88-92.

2. Ball, P.W.; Getliffe, F.M. Satureja L. In Flora Europaea; Tutin, T.G., Heywood, V.H., Burges, N.A., Moore, D.M., Valentine, D.H., Walters, S.M., Webb, D.A., Eds.; Cambridge University Press: London, UK, 1972; Volume 3, pp. 163-165.

3. Rios, J.L.; Recico, M.C. Medicinal plants and antimicrobial activity. J. Ethnopharmacol. 2005, 100, 80-84.

4. Capone, W.; Mascia, C.; Spanedda, L.; Chiappini, M. Chemical composition and antibacterial activity of the essential oil from sardinian Satureja thymbra. Fitoterapia 1989, 60, 90-92.

5. Gulluce, M.; Sokmen, M.; Daferera, D.; Agar, G.; Ozkan, H.; Kartal, N. In vitro antibacterial, antifungal and antioxidant activities of the essential oil and methanol extracts of herbal parts and callus cultures of Satureja hortensis L. J. Agric. Food Chem. 2003, 51, 3958-3965.

6. Zargari, A. Medicinal Plants. Tehran University Press: Tehran, Iran, 1990; Volume IV, pp. 325-328.

7. Gören, A.C.; Topçu, G.; Bilsel, G.; Bilsel, M.; Wilkinson, J.M.; Cavanagh, H.M.A. Analysis of essential oil of Satureja thymbra by hydrodistillation, thermal desorber, and headspace GC/MS techniques and its antimicrobial activity. Nat. Prod. Res. 2004, 18, 189-195.

8. Sarac, N.; Ugur, A. Antimicrobial activities of the essential oils of Origanum onites L., Origanum vulgare L. subspecies hirtum (Link) Ietswaart, Satureja thymbra L., and Thymus cilicicus Boiss. \& Bal. growing wild in Turkey. J. Med. Food 2008, 11, 568-573.

9. Azaz, A.D.; Kürkcüoglu, M.; Satil, F.; Baser, K.H.C.; Tümen, G. In vitro antimicrobial activity and chemical composition of some Satureja essential oils. Flavour Fragr. J. 2005, 20, 587-591.

10. Loizzo, M.R.; Saab, A.M.; Tundis, R.; Statti, G.A.; Menichini, F.; Lampronti, I.; Gambari, R.; Cinatl, J.; Doerr, H.W. Phytochemical analysis and in vitro antiviral activities of the essential oils of seven Lebanon species. Chem. Biodivers. 2008, 5, 461-470.

11. Chorianopoulos, N.G.; Giaouris, E.D.; Skandamis, P.N.; Haroutounian, S.A.; Nychas, G.-J.E. Disinfectant test against monoculture and mixed-culture biofilms composed of technological, spoilage and pathogenic bacteria: Bactericidal effect of essential oil and hydrosol of Satureja thymbra and comparison with standard acid-base sanitizers. J. Appl. Microbiol. 2008, 104, 1586-1596.

12. Cetin, H.; Cilek, J.E.; Oz, E.; Aydin, L.; Deveci, O.; Yanikoglu, A. Acaricidal activity of Satureja thymbra L. essential oil and its major components, carvacrol and gamma-terpinene against adult Hyalomma marginatum (Acari: Ixodidae). Vet. Parasitol. 2010, 170, 287-290.

13. Ayvaz, A.; Sagdic, O.; Karaborklu, S.; Ozturk, I. Insecticidal activity of the essential oils from different plants against three stored-product insects. J. Insect Sci. 2010, 10, 1-13. 
14. Shafie, M.S.B.; Hasan, Z.; Shah, R.M. Study of genetic variability of Wormwood capillary (Artemisia capillaris) using inter simple sequence repeat (ISSR) in Pahang region, Malaysia. Plant Omics J. 2009, 2, 127-134.

15. Pourohit, S.S.; Vyas, S.P. Medicinal Plants Cultivation; Agrobios Press: Jodhpur, India, 2004.

16. Rahimmalek, M.; Tabatabaei, B.E.S.; Etemadi, N.; Goli, S.A.H.; Arzani, A.; Zeinali, H. Essential oil variation among and within six Achillea species transferred from different ecological regions in Iran to the field conditions. Ind. Crops Prod. 2009, 29, 348-355.

17. Basu, S.K.; Acharya, S.N.; Bandara, M.S.; Friebel, D.; Thomas, J.E. Effects of genotype and environment on seed and forage yield in fenugreek (Trigonella foenum-graecum L.) grown in western Canada. Aust. J. Crop Sci. 2009, 3, 305-314.

18. Mockute, D.; Bernotiene, G.; Judzentiene, A. The essential oil of Origanum vulgare L. ssp. Vulgare growing wild in Vilnius district (Lithuania). Phytochemistry 2001, 57, 65-69.

19. Russell, M.F.; Southwell, I.A. Monoterpenoid accumulation in 1,8-cineol, terpinolene and terpinen-4-ol chemotypes of Melaleuca alternifolia seedlings. Phytochemistry 2003, 62, 683-689.

20. Curado, M.A.; Oliveira, C.B.A.; Jesus, J.G.; Santos, S.C.; Searphin, J.C.; Ferri, P.H. Environmental factors influence on chemical polymorphism of the essential oils of Lychnophora ericoides. Phytochemistry 2006, 67, 2363-2369.

21. Letchamo, W.; Xu, H.L.; Gosselin, A. Variations in photosynthesis and essential oil in thyme. J. Plant Physiol. 1995, 147, 29-37.

22. Karousou, R.; Koureas, D.N.; Kokkini, S. Essential oil composition is related to the natural habitats: Coridothymus capitatus and Satureja thymbra in NATURA 2000 sites of Crete. Phytochemistry 2005, 66, 2668-2673.

23. Sokovic, M.; Tzakou, O.; Pitarakoli, D.; Couladis, M. Antifungal activities of selected aromatic plants growing wild in Greece. Food / Nahrung 2002, 46, 317-320.

24. Skoula, M.; Grayer, R.J. Volatile oils of Coridothymus capitatus, Satureja thymbra, Satureja spinosa and Thymbra calostachya (Lamiaceae) from Crete. Flavour Fragr. J. 2005, 20, 573-576.

25. Schulz, H.; Ozkan, G.; Baranska, M.; Krüger, H.; Özcan, M. Characterisation of essential oil plants from Turkey by IR and Raman spectroscopy. Vib. Spectrosc. 2005, 39, 249-256.

26. Chorianopoulos, N.; Evergetis, E.; Mallouchos, A.; Kalpoutzakis, E.; Nychas, G.-J.; Haroutounian, S.A. Characterization of the essential oil volatiles of Satureja thymbra and Satureja parnassica: Influence of harvesting time and antimicrobial activity. J. Agric. Food Chem. 2006, 54, 3139-3145.

27. Michaelakis, A.; Theotokatofs, S.A.; Koliopoulos, G.; Chorianopoulos, N.G. Essential oils of Satureja species: Insecticidal effect on Culex pipiens larvae (Diptera: Culicidae). Molecules 2007, 12, 2567-2578.

28. Economou, G.; Panagopoulos, G.; Tarantilis, P.; Kalivas, D.; Kotoulas, V. Variability in essential oil content and composition of Origanum hirtum L., Origanum onites L., Coridothymus capitatus (L.) and Satureja thymbra L. populations from the Greek island Ikaria. Ind. Crops Prod. 2011, 33, 236-241.

29. Piras, A.; Cocco, V.; Falconieri, D. Isolation of the volatile oil from Satureja thymbra by supercritical carbon dioxide extraction: Chemical composition and biological activity. Nat. Prod. Commun. 2011 6, 1523-1526. 
30. Karpouhtsis, I.; Pardali, E.; Feggou, E.; Kokkini, S.; Scouras, Z.G.; MavraganiI-Tsipidou, P. Insecticidal and genotoxic activities of oregano essential oils. J. Agric. Food Chem. 1998, 46, 1111-1115.

31. Ravid, U.; Putievsky, E. Constituentsof the essentail oils from Majorana syriaca, Coridothymus capitatus and Satureja thymbra. Planta Med. 1983, 49, 248-249.

32. Galego, L.; Almeida, V.; Gonçalves, V.; Costa, M.; Monteiro, I.; Matos, F.; Miguel, G. Antioxidant activity of the essential oils of Thymbra capitata, Origanum vulgare, Thymus mastichina and Calamintha baetica. Acta Hortic. 2008, 765, 325-334.

33. Albano, S.M.; Lima, A.S.; Miguel, M.G.; Pedro, L.G.; Barroso, J.G.; Figueiredo, A.C. Antioxidant, anti-5-lipoxygenase and antiacetylcholinesterase activities of essential oils and decoction waters of some aromatic plants. Rec. Nat. Prod. 2012, 6, 35-48.

34. Ruberto, G.; Baratta, M.T. Antioxidant activity of selected essential oil components in two lipid model systems. Food Chem. 2000, 69, 167-174.

35. Glamočlija, J.; Soković, M.; Vukojević, J.; Milenković, I.; van Griensven, L.J.L.D. Chemical composition and antifungal activities of essential oils of Satureja thymbra L. and Salvia pomifera ssp. calycina (Sm.) Hayek. J. Essent. Oil Res. 2006, 18, 115-117.

36. Marković, T.; Chatzopoulou, P.; Šiljegović, J.; Nikolić, M.; Glamočlija, J.; Ćirić, A.; Soković, M. Chemical analysis and antimicrobial activities of the essential oils of Satureja thymbra L. and Thymbra spicata L. and their main components. Arch. Biol. Sci. 2011, 63, 457-464.

37. Adams, S.; Kunz, B.; Weidenbörner, M. Mycelial deformations of Cladosporium herbarum due to the application of eugenol and carvacrol. J. Essent. Oil Res. 1996, 8, 535-540.

38. Adam, K.; Sivropoulu, A.; Kokkini, S.; Lanaras, T.; Arsenakis, M. Antifungal activities of Origanum vulgare subsp. hirtum, Mentha spicata, Lavandula angustifolia and Salvia fruticosa essential oils against human pathogenic fungi. J. Agric. Food Chem. 1998, 46, 1739-1745.

39. Skandamis, P.; Koutsoumanis, K.; Fasseas, K.; Nychas, G.-J.E. Inhibition of oregano essential oil and EDTA on Escherichia coli O157:H7. Ital. J. Food Sci. 2001, 13, 65-75.

40. Carson, C.F.; Mee, B.J.; Riley, T.V. Mechanism of action of Melaleuca alternifolia (tea tree) oil on Staphylococcus aureus determined by time-kill, lysis, leakage and salt tolerance assays and electron microscopy. Antimicrob. Agents Chemother. 2002, 46, 1914-1920.

41. Knobloch, K.; Weigand, H.; Weis, N.; Schwarm, H.M.; Vigenschow, H. Action of Terpenoids on Energy Metabolism. In Progress in Essential Oil Research; Brunke, E.J., Ed.; Walter de Gruyter: Berlin, Germany, 1986; pp. 429-445.

42. Sikkema, J.; de Bont, J.A.M.; Poolman, B. Interactions of cyclic hydrocarbons with biological membranes. J. Biol. Chem. 1994, 269, 8022-8028.

43. Burt, S. Essential oils: Their antibacterial properties and potential applications in foods-A review. Int. J. Food Microbiol. 2004, 94, 223-253.

44. Denyer, S.P.; Hugo, W.B. Biocide-Induced Damage to the Bacterial Cytoplasmic Membrane. In Mechanisms of Action of Chemical Biocides; Denyer, S.P., Hugo, W.B., Eds.; The Society for Applied Bacteriology, Technical Series No 27. Oxford Blackwell Scientific Publication: Oxford, UK, 1991; pp. 171-188. 
45. Soković, M.; Glamočlija, J.; Marin, D.P.; Brkić, D.; van Griensven, J.L.D.L. Antibacterial effects of the essential oils of commonly consumed medicinal herbs using an in vitro model. Molecules 2010, 15, 7532-7546.

46. Cosentino, S.; Tuberoso, C.I.G.; Pisano, B.; Satta, M.; Mascia, V.; Arzedi, E.; Palmas1, F. In-vitro antimicrobial activity and chemical composition of Sardinian Thymus essential oils. Lett. Appl. Microbiol. 1999, 29, 130-135.

47. Kalemba, D.; Kunicka, A. Antibacterial and antifungal properties of essential oils. Curr. Med. Chem. 2003, 10, 813-829.

48. Nikaido, H.; Vaara, M. Molecular basis of bacterial outer membrane permeability. Microbiol. Rev. 1985, 49, 1-32.

49. Nikaido, H. Outer membrane barrier as a mechanism of antimicrobial resistance. Antimicrob. Agents Chemother. 1989, 33, 1831-1836.

50. Gao, Y.; Van Belkum, M.J.; Stiles, M.E. The outer membrane of gram negative bacteria inhibits antibacterial activity of brochocin-C. Appl. Environ. Microbiol. 1999, 65, 4329-4333.

51. Nikaido, H. Prevention of drug access to bacterial targets: Permeability barriers and active efflux. Science 1994, 264, 382-388.

52. Delamare, A.P.L.; Moschen-Pistorello, I.T.; Artico, L.; Echeverrigaray, L.A.S. Antibacterial activity of the essential oils of Salvia officinalis L. and Salvia triloba L. cultivated in South Brazil, Food Chem. 2007, 100, 603-608.

53. Marino, M.; Bersani, C.; Comi, G. Impedance measurementsto study the antimicrobial activity of essential oils from Lamiaceae and Compositae. Int. J. Food Microbiol. 2001, 67, 187-195.

54. Cowan, M.M. Plant products as antimicrobial agents. Clin. Microbiol. Rev. 1999, 12, 564-582.

55. Wendakoon, C.N.; Sakaguchi, M. Inhibition of amino acid decaboxylase activity of Enterobacter aerogenes by active components of spices. J. Food Prot. 1995, 58, 280-283.

56. Farag, R.S.; Daw, Z.Y.; Hewedi, F.M.; El-Baroty, G.S.A. Antimicrobial activity of some Egyptian spice essential oils. J. Food Prot. 1989, 52, 665-667.

57. Lemos, T.L.G.; Matos, F.J.A.; Alencar, J.W.; Craveiro, A.A.; Clark, A.M.; McChesney, J.D. Antimicrobial activity of essential oils of Brazilian plants. Phytoter. Res. 1990, 4, 82-84.

58. Smith-Palmer, A.; Stewart, J.; Fyfe, L. Antimicrobial properties of plant essential oils and essences against five importantfood-borne pathogens. Lett. Appl. Microbiol. 1998, 26, 118-122.

59. British Pharmacopoeia II. P 109, H.M. Stationary Office: London, UK, 1980.

60. Adams, R.P. Identification of Essential Oil Components by Gas Chromatography/Mass Spectrometry, 4th ed.; Allured Publ. Corp.: Carol Stream, IL, USA, 2007; pp. 10-87.

61. Blois, M.S. Antioxidant determinations by the use of a stable free radical. Nature 1958, 181, 1199-1200.

62. Booth, C. Fungal Culture Media. In Methods in Microbiology; Norris, J.R., Ribbons, D.W., Eds.; Academic Press: New York, NY, USA, 1971; Volume IV, pp. 49-94.

63. Daouk, K.D.; Dagher, M.S.; Sattout, J.E. Antifungal activity of the essential oil of Origanum syriacum L. J. Food Prot. 1995, 58, 1147-1149.

64. Hanel, H.; Raether, W. A more sophisticated method of determining the fungicidal effect of water-insoluble preparations with a cell harvester, using miconazole as an example. Mycoses 1988, 31, 148-154. 
65. Espinel-Ingroff, A. Comparasion of the E-test with the NCCLS M38-P method for antifungal susceptibility testing of common and emerging pathogenic filamentous fungi. J. Clin. Microbiol. 2001, 39, 1360-1367.

66. Kabara, J.J. Phenols and Chelators. In Food Preservatives; Russell, N.J., Gould, G.W., Eds.; Blackie: London, UK, 1991; pp. 200-214.

Sample Availability: Samples of the essential oils are available from Abdulhamid Giweli.

(C) 2012 by the authors; licensee MDPI, Basel, Switzerland. This article is an open access article distributed under the terms and conditions of the Creative Commons Attribution license (http://creativecommons.org/licenses/by/3.0/). 